\title{
Imposture in Decline and Fall
}

\author{
Manuel Megías Rosa \\ Universidad de Alcalá de Henares
}

\begin{abstract}
This article deals with an analysis of the characters in Decline and Fall, and the position they occupy in the novel. The main theme of the article is imposture. Paul Pennyfeather, the protagonist of the novel, goes from place to place, making a circular movement whose starting is also its end. Following Paul Pennyfeather, I try to demonstrate that most of the characters of the novel occupy a place that does not belong to them.
\end{abstract}

\section{Introduction}

I regard writing not as investigation of character but as an exercise in the use of language, and with this I am obsessed. I have no technical psychological interest. It is drama, speech and events that interest me.

The above paragraph can be found on the first page of Decline and Fall and indicates clearly Waugh's ideas when facing a literary work. These statements and the circular structure of the book have been the basis for the elaboration of the present article.

The eternal reappearances and mutations that take place in the characters have also been the theme of this work: from being a criminal to becoming an executioner; from being criticised to criticising, all of it as a result of fate which manages the characters and the whirl which envelops them. But it is imposture that has mainly called my attention. The characters of the novel occupy a place that does not belong to them, they are taking the post of somebody else and this will be the main theme of the present paper.

Following Paul in his travels, Waugh satirizes what Paul encounters: the Establishment's education system, the state church, high society, the legal system, politics and politicians, the penal system and the nineteenth century idea of the gentleman, the whole code of the ready made honour that is still the small voice, trained to command, of the Englishman all over the world. (Heath 65) 
All these aspects appear in Decline and Fall nearly in the same order. There are many specialists in the novels of Waugh, who are expert on his works and his literary devices, whose duty has consisted in underlining the most important features of Decline and Fall. Some of them stress learnedly the classical references of the novel, its original manuscript, what the characters have in them of former characters, what they symbolized, Waugh and his time, etc. But these specialists often forget that the echoes which constitute an artist's inspiritation are entirely a matter of chance in many cases: mere cultural influences whose non-existence would have seriously endangered human progress; they are simply inspiring Muses who help man to express his inner ego, in this case, the vision of a society with which Waugh is not in agreement, but where he is obliged to live and which he must respect.

Evelyn Waugh uses irony to move to laughter and ridicule. He makes use of both farce and satire at the same time. Paul Pennyfeather, the protagonist of the novel covers the distance which goes from Oxford to Llanabba School, from there to Mayfair in London; from London to two consecutive prisons and, finally, back to Oxford. It is a circular movement whose starting points is also the final point where Pennyfeather goes back to deal with the activities he had to renounce. I compare that circle to a play in three acts whose main settings are a Secondary School in Wales, an elegant district in London and a prison, besides a college in Oxford, the town of Marseille and the island of Corfu as secondary settings.

\section{First act}

The protagonist of the novel is obliged to abandon the place in which he studies theology. Pennyfeather is not a member either of a noble or wealthy family and that tiny detail is not to be forgiven at Scone College: “But it is quite right. It isn't Reading. It's Penny Feather-someone of no importance" (Decline and Fall 13). Paul Pennyfeather is accused of indecendent behaviour ${ }^{1}$ but he is not guilty, as he is not guilty when he is sent to prison in the third part of the book charged with a crime he has not committed either. In both cases, Paul occupies the place of the real guilty person and also on both occasions the guilty person belongs to the upper class. Decline and Fall is a farce from beginning to end. Lies and deceits impregnate Pennyfeather's stay at Llanabba School. ${ }^{2}$ Waugh emphasizes this institution's double face as follows:

From the back it looks very much like other large country houses ... but from the front—and that's how it was aproached from Llanabba station-it is formidably feudal. (Decline and Fall 20)

Waugh parodies both the refined and distinguished colleges in Oxford and the public secondary schools to which the upper classes send their children.

At Llanabba School Pennyfeather becomes a teacher in spite of the fact that he has not completed his education; neither Grimes or Prendergast, his new colleagues, are real teachers. Prendergast is a failed clergyman who was once a rector of a "beautiful church" 
that he had to abandon afflicted by "doubts." Grimes is a character of uncertain reputation who has had different jobs before becoming a teacher and who does whatever he wants. ${ }^{3}$

Grimes enters and leaves the book on several occasions. The reader always finds him in the same setting in which Pennyfeather moves. Grimes seems to be a symbol of one of the two faces of misfortune; Paul another. Paul meets adversity by chance. Grimes looks for and deserves it. Grimes is a symbol of disorder, of human egoism and lack of principles: although he is married, he does not hesitate to marry a daughter of Mr. Fagan's, owner and headmaster of Llanabba school, and to leave the place alone when his secret is about to be discovered. He simulates his own suicide so nobody might run after him. J. B. Priestly considers Grimes one of Waugh's great achivements: "Mr. Waugh has done something very difficult to do, he has created a really comic character" (84). Jeoffry Heath considers Grimes the dominant character in the novel: "Grimes is a resilient survival hero ... his story is a caricature of history of barbarism" (65). Paul, on the other hand, is a weak, inactive character; he is extremely ingenuous and innocent and lacks a defined personality: not long time settling at Llanabba School, Paul receives a letter from Scone College. In it, his friend Potts tells him that Digby-Vane Trumpigton, responsible for Paul's expulsion, wants to compensate him and asks him to accept twenty pounds. Paul does not know whether to accept it or not. The code of honour tells him, on one hand, not to receive it, on the other hand, that money would be very convenient. Eventually Paul decides to refuse the offering so that he could have a clear conscience. Nevertheless and surprisingly, he receives another letter from Potts in which his friend encloses a twenty pound cheque. ${ }^{4}$ It has been Grimes who has decided for him and has solicited the money in the name of Paul: "Well, I am a gentleman too, old boy", said Grimes "and I was afraid you might feel like that, so I did my best for you and saved you from yourself" (Decline and Fall 45). Pennyfeather does not get angry. He leaves the code of honour aside and accepts the money.

Together with those false teachers and gentlemen, we meet another curious character: Philbrick, the butler. A born faker who pretends to be someone of importance come down in the world. He insists on telling everyone the history of his life:

"I expect you wonder how it is that I came to be here?" said Philbrick. "No", said Paul firmly, "nothing of the kind. . . ." "I'll tell you," said Philbrick, "it was like this. ..." (Decline and Fall 51)

Philbrick tells Paul one of his biographies in spite of Paul's insistence and the irony he spreads throughout the conversation. In chapter XI, Prendergast takes pity on Philbrick who has told him something very surprising:

"It impressed me very much. You see, Philbrick is really Sir Solomon Philbrick, the shipowner."

"The novelist, you mean," said Grimes.

"The retired burglar," said Paul.

The three masters looked at each other. "Old boys, it seems to me that someone's been pulling our legs." (Decline and Fall 2) 
Philbrick will appear three more times in the novel: in the streets of London, in the prison where he pretends to be the governor's brother and, at the end of the book, waving to Paul from the back seat of a luxury car. ${ }^{5}$

Therefore, having those individuals on duty as teachers, it is not a surprise to see that Llanabba School is not the most suitable place for acquiring education and knowledge. The students of Llanabba School do not feel any kind of respect for their masters and it is not their fault. Paul is the only teacher they take into consideration: he is the youngest teacher and he has got a number of protectors among some of the most influential pupils of the school. In relation to it we can hear Beste-Chewynde say:

"Well, Clutterbuck was in the matron's room this morning. He'd just got a tin of pineapple chunks. Tangent said: are you going to take that in to Hall?," and he said "no, I'm going to eat them in Mr. Pennyfeather's hour." "Oh no, you are not," said Tangent, "sweets and biscuits are one thing but pineapple chunks are going too far. It's little stinkers like you, he said, "who turn decent masters savage." (Decline and Fall 40)

If teachers at Llanabba School are incompetent, its headmaster, Dr. Fagan, is not less. His school is a complete farce, "the back of the building" as it was said before. Every celebration held there is a fake and Dr. Fagan seems to strive at it, not consciously, of course, but in his desire to mask and disguise the reality of the school he leads. Appearances are the most important thing. Not in vain we find there, as visitors, the Countess of Circumference and Mrs. Beste-Chetwynde among other "grandees" of English aristocracy:

"It doesn't do to let a boy win more than two events, (says Dr. Fagan). I leave you to arrange that. I think it would be only right if little Lord Tangent won something, and Beste-Chetwynde-yes, his mother is coming down, too." (Decline and Fall 49)

"The Sports", one of the funniest chapters of the book, is a good example of fake. Firstly, the champagne is not for the teachers; secondly, the sandwiches are numbered and thirdly, the band's aspect and music are abominable: "I refuse to believe the evidence of my eyes,' said the doctor. 'Those creatures simply don't exist"' (Decline and Fall 64).

We can find very funny and extravagant situations throughout the chapter, from Philbrick's accidental shot in Lord Tangent's ankle when giving the command to start the race, ${ }^{6}$ to the semi-vulgarity with which the aristocratic ladies and gentlemen defend their children. Everything in the chapter is amusing but at the end of the chapter amusement turns into delirium when the party is joined by Mrs. Margot Beste-Chetwynde and her "negro" lover. Nobody can understand "Chokie's" influence upon the lady: "IIts queer,' said Flossie, 'that a woman with as much money as Mrs. Beste-Chetwynde should wear such 'dull' clothes." (Decline and Fall 81). Even cool Prendergast dares to say: "The mistake was giving them (meaning Chokie and black people in general) their freedom ... They were far happier and better looked after before" (Decline and Fall 81).

Chokie and Margot's behaviour calls everybody's attention. It will be Grimes who makes Paul understand why they behave like that: 
"I don't suppose she trots with him just for the uplift of his conversation, do you?"

"No, I suppose not."

"In fact I don't mind diagnosing a simple case of good old sex." (Decline and Fall 85) ${ }^{7}$

Inexplicably, Paul also feels atracted by Mrs. Beste-Chetwynde. The first part of the book closes referring to the regrettable situation Llanabba School is going through. The night of Grimes and Flossie's wedding, Diana, the maid, heats the bed with "the remains of a desk and two of the boys' playboxes." In this distressing circumstances the boys began packing to go away for the Easter holidays. Paul will also leave the book for a few pages which Waugh will use to describe King's Thursday and its history.

\section{Second act}

From now on the book becomes more serious and loud laughter is restrained. Criticism never stops being biting, however. Paul declares his love to Margot and promises not to go back to Llanabba School. Margot accepts his offer of marriage and persuades him to help her with her economic affairs. In the first part of the book Waugh pays attention to criticizing the teaching system and schools. In the second part of the novel his criticism is centred on society by means of Margot Beste-Chetwynde and her business. The setting in this part is radically different from the previous one: King's Thursday, an ancient mansion that Margot has acquired and that has been completely modernized by her friend Professor Silenious so it looked in accordance with the ultramodern architectural manners of that time. ${ }^{8}$ It is Professor Silenious himself who says: "Nothing I have ever done has caused me so much disgust. I hate every bit of it" (Decline and Fall 125). Lady Vanburgh, a friend of the family, also has her own opinion about the place: "The drains were satisfactory, but, of course, they were underground" (Decline and Fall 125).

The owner of the house, Mrs. Beste-Chetwynde is a hollow character, a stereotype of whom Waugh offers only one face (perhaps the only face she has). Whenever she appears in the book, she always performs the same scene; a scene which transforms her into a scarcely credible character: an operetta actress whose existence is based on eccentricity, coolnes and the necessity of finding a husband. Like the rest of the characters she occupies a place that does not belong to her for, as we will see later, she is not the respectable lady she pretends to be. Paul is absolutely captivated by her beauty whereas Professor Silenious does not think she differs much from other women of her age:

A few milimetrs here and a few milimetres there, such variations arte inevitable in the human reproductive system; but in all her essential functions-her digestion, for example-she conforms to type. (Decline and Fall 149)

Professor Silenius'view of Margot contrasts enormously with her social success. Her wedding with Paul occupies everyone's attention. Hundreds of people, provided with food and other items, crowd together since the day before the ceremony to catch a glimpse of such a peculiar couple: 
The police were force to make several batoncharges and many guests were crushed almost to death in their attempt to reach the doors, and the route down which Margot had to drive was lined as for a funeral with weeping and hysterical women. (149)

It can be said without hesitation that Margot's marriage with Paul is suspended due to her fears of being arrested in case she presented herself in Marseille to clarify Paul's innocence. In a few pages, from the very moment Margot was included in the book, the reader has been aware of her love affair with a coloured man, her three consecutive marriage proposals to Professor Silenious, her doubts about whether to marry Mr. Maltravers or not, and later in the novel, her flirtation with Trumpington and her eventual union with Maltravers.

Margot does not ever mention the real nature of her business, but it is all quite clear for the reader (not for Paul) when she interviews several applicants who desire to work for her. Her business is prostitution in South America, where she sends the girls. Paul is arrested in Marseille for dealing with Margot's affairs and the only thing which occurs to him when he is informed why he has been detained, is to think that "there had been nothing noticeably light-hearted in Margot's conduct of her business" (147).

It is Paul who goes to Marseille instead of Margot. In less than one page he can be seen going along the streets in the lower part of the town in order to solve Margot's problems. Paul has no alternative but to bribe the French authorities to be able to take the girls out of the country. His reliance in Margot is heroic: "How typical of Margot (he thinks) that in the whirl of luxury, she should still have time to care for the poor girls she had unwittingly exposed to such perils" (152). The second part of the book closes with Paul's arrest. Margot Beste-Chetwynde is directly responsible for it. It is the second time Paul has been charged which a crime he has not committed; it is third time he occupies a place that does not belong to him; it is also the second time he is refused a place among the narrow social circle to which he would like to belong.

\section{Third act}

From the start of the novel we know that this is a world which is arbitrary, without anything but the appearance of justice and the moral legal codes being exploited for the convenience of characters. Margot's name is not mentioned during the trial that leads Paul to prison because she has a wide circle of inluential acquaintances among the members of goverment. Maltravers is one of them.

Paul's attitude when confined in prison is puzzling for the reader. It cannot be said that being there seemed something natural for him, but when he finally enters his cell and face the prospect of a month's confinement, he feels strengthened:

It was the first time he had been really alone for for months. How refreshing it was, he reflected... The next few weeks of solitary confinement were among the happiest of Paul's life. (169-70) 
The reader knows he is innocent and cannot understand how he is able to endure such a destiny.

For the penitentiary authorities Paul is a criminal, therefore he must be like the rest of the criminals. The privilege of forming a part of the human race leaves the man when he sets foot in prison, and that is evident in the novel when Paul is interviewed by several "professionals" who remind us of Llanabba school and its masters-in fact, two of them, old Prendergast and Philbrick reappear here as a prison priest and a prison guard respectively. ${ }^{9}$ As Llanabba School's staff, none of them seem to know their job. The doctor thinks that Paul is pulling his leg and finds him suitable for any kind of torture; the prison teacher considers him illiterate and gives him an English grammar to while away the time during his month's confinement; the priest, old Prendergast, informs him about the "flexible" rules to attend the religious services held in the prison: "Services are voluntary - that is to say, you must either attend all or none" (165); and finally, Sir Wilfred Lucas-Dockery, the Governor of the prison, who is, perhaps, the least suitable person to occupy that post.

Sir Wilfred's peculiar ideas about criminal psychology lead him to experiment special treatments with the prisoners in order to modify their behaviour. Nearly everybody in the prison tries to tell him how dangerous his measures are but Sir Wilfred does not pay attention to their advice and Prendergast will be killed by one of the prisoners with one of the sharp tools he had issued to the Arts and Crafts School. From the moment of the priest's death on, "it was observed that the Chief Warden seemed to have more influence with his superior than he had had before" (184).

Paul indolence becomes resignation at Egdon Heath Penal Settlement, a prison where he is transferred. Grimes, who is serving a three year sentence, is also there.$^{10}$ In this new prison, things come to be very different for Paul as he receives privileged treatment: new books, caviar, flowers, etc. Paul accepts uncomplainingly to be in the place of Margot but he cannot understand why he is permitted to be given such a large number of presents.

Shortly after having been moved there he receives a letter from Margot and some time later Margot herself visits the prison. During the visit Margot decides to marry Maltravers for two reasons. Firstly, her social circle is starting to think she is not the woman they thought she was, and becoming the wife of a minister would help her recover her reputation; secondly, she wishes to see Paul away from prison and Maltravers is the only one who can do it immediately: altruism-it has to be seen like that because the reader knows the character well-and usefulness at the same time. That is the ideal moment to kill two birds with one stone.

Grimes escapes (again) from prison and Pennyfeather is taken to a sanatorium to be operated for appendicitis. Neither the reader, who fears for Paul's life, nor Paul himself who protests because he had already been operated for appendicitis when he was a child, knows that Margot has planned Paul's false death very carefully. The director of the sanatorium is Dr. Fagan in whose "capable hands" Paul is left.

The last part of the book is resolved quickly and at the end of the novel we see Paul settled at his old college in Oxford. He has kept his surname but changed his first name and has started to study theology again. Now he has a beard and says Paul Pennyfeather was a cousin of his, a remote cousin. Nobody seems to have recognized him. 
Decline and Fall closes with a conversation between Paul and Peter Beste-Chetwynde in Paul's bedroom three years later. Peter is an alcoholic and Paul is not interested in the past at all. Now he has got Sniggs and his former enemies on his side. The circle has been completed. If another Pennyfeather were expelled from Scone College, Paul would be seen from a very different point of view. He would probably be one of those responsible for the expulsion. He has become less innoncent. Now he is a conscious impostor and as such part of the system.

\section{Conclusion}

Although Decline and Fall is Evelyn Waugh's first novel, it was so well received by the public that it meant Waugh's consolidation as a writer. Most critics agree that Decline and Fall is a clever, funny novel in which language is used as a masterly instrument for criticism. Waugh is a critic of life whose weapon is the joke disguised as the simple statement.

Seven years before Decline and Fall was published, another novel, Crome Yellow had caused Aldous Huxley, its author, a lot of problems. In that novel, Huxley ridicules the society of the twenties, the same society drawn in the pages of Decline and Fall. Nevertheless, when comparing both works (Lady Circumference's corpulence reminds us of Pricilla Winbush's coiffures and Pennyfeather makes us think about Dennis Stone, both as responsible for the plot of either novel) a more serene irony and mockery can be found int the later one, besides, the characters are less erudite, homogeneous and worked out. With his novel Aldous Huxley won the antipathy of some of his friends and even some of his relatives who recognized themselves —or at least believed so, in the pages of the book. Evelyn Waugh's characters are, on the other hand, less convincing. There's nothing in them that remind us of flesh and blood beings. They exist from the very moment they bear the social criticism that Waugh carries out, they are characters of confusing psychology driven more by fate than by destiny. All of them are used by Waugh as representatives of two kinds of social status: the privileged and the ones who want to resemble them. Most of them worship appearances and ocupy a place that is not theirs. Imposture is their queen and injustice their sentence.

\section{Notes}

1. "In absence of authority, the atavistic aristocrats attack a typical modern man. Their victim is polite Paul Pennyfeather, an abstemious man and overwhelmingly dull theology student who is consumedly shy of drunkards" (Heaths 66).

2. It is fate that leads Paul from Scone College, where he is an ordinary pupil, to Llanabba School where he becomes a teacher as if by magic.

3. "Decline and Fall was heavily censored by Chapman and Hall after it had been refused by Duckworth's on the grounds of indecency. In the original manuscript, for instance, Captain Grimes is clearly involved in homosexual relationship with the boy Cluttebuck" (Stannard 83, 84). 
4. In chapter VIII the reader finds out how Trumpington had got the money:

“That's very interesting Greta. Mr. Pennyfoot (instead of Pennyfeather) knows Alastair”. "Does he?"

"That boy is doing no good for himself. Got fined twenty pound the other day, his mother told me." (Decline and Fall 69)

5. "Like Grimes, he survives all bad fortune; masquerading as a butler, a burglar, a gambler, a novelist, a cinema magnate, he has no real identity and represents the featureless interchangeability of an age devoid of distinct moral values" (Heath 68).

6. Using a trick he learned from Ronald Firbank, Waugh tells us at intervals that Tangent's foot has turned black, that it has been amputated, and eventually, apropos of something else, that Tangent has died (Heath 68).

7. "A simple case of fornication" in the original manuscript (Davies 46).

8. The house dimensions are clear int eh following quotation:

"Where's everybody?"

"I think Peter's taking them on a tour round the house. It's much more elaborated than it looks from the outside." (Decline and Fall 129)

9. Dr. Fagan has got rid of Llanabba Castle and all his employees have dispersed.

10. "The way in which characters return again and again in different roles or guises ... is part of the novel's burlesque quality, demanding that we accept a different set of probabilities than those in life" (Bradbury 42).

\section{Works Cited}

Bradbury, Malcolm. Evelyn Waugh. Edinburgh: Oliver and Boyd, 1964.

Davis, Robert Murray. Evelyn Waugh, Writer. Norman: Pilgrim Books, 1981.

Heath, Jeffrey. The Picturesque Prison: Evelyn Waugh and His Writings. London: Weidenfel and Nicholson, 1982.

Stannard, Martin. Evelyn Waugh:The Critical Heritage. London: Routgedge and Keagan Paul, 1984.

Waugh, Evelyn. Decline and Fall. 1928. Harmondsworth: Penguin Books, 1937. 